\title{
KINGDOM-CENTERED MISSION IN INDONESIAN CONTEXT
}

\author{
Goenawan Susanto Hadianto \\ Sekolah Tinggi Theologia Abdiel \\ gunawan64@gmail.com
}

\begin{abstract}
Abstrak
Paper ini mendiskusikan konsep misi yang berpusat pada kerajaan allah dan aplikasinya dalam konteks indonesia. Pemaparannya tulisan ini dibagi ke dalam dua bagian, yakni pertama menjelaskan konsep misi yang berusat pada Kerajaan Allah: munculnya konsep ini dalam sejarah, dan artinya dari pengajaran biblika. Bagian kedua mendiskusikan empat bagian yang meliputi: hubungan agama Kristen dengan agama-agama; memahami misi dalam konteks Indonesia; konsep holistik pertumbuhan gereja; dan dialog antara agama dan kesaksian Kristen.
\end{abstract}

Kata kunci: Kerajaan Allah, Misi, Konteks Indonesia, Dialog, Agama-Agama

\section{Introduction}

"The age of missions is at an end; the age of mission has begun," Stephen Neill boldly proclaimed in his book referring the new emerging understanding of mission. ${ }^{1}$ The understanding of mission has changed from the concept of "missions" (in plural form) with churches as the main subjects to the concept of "mission" (in singular form) with the Trinity as the main subject. It was at Willingen Conference of the IMC (1952) that the new concept of mission, namely Missio Dei, surfaced clearly. Mission is no longer understood primarily as an activity of the Church but as an attribute of God. It is derived from the very nature of God and put in the context of the doctrine of the Trinity, not of ecclesiology or soteriology. $^{2}$

The latter half of the nineteenth century and the first half of the twentieth were largely dominated by the Church-centered concept of mission. This concept, prominent around the middle of the nineteenth century through the work of Henry Venn and Rufus Anderson, set forth the view that church planting should be considered an important goal

\footnotetext{
${ }^{1}$ Stephen Neill, A History of Christian Missions. (Harmondsworth: Penguin, 1966), 572.

${ }^{2}$ David J. Bosch, Transforming Mission. Paradigm Shifts in Theology of Mission. (Maryknoll, NY: Orbis Books, 1991), 390.
} 
of mission, alongside personal conversion. ${ }^{3}$ In this understanding, planting new churches and expansion of the denominational churches in the mission fields constitute the essential activity of mission.

According to James Scherer, the Church-centered concept of mission did not fully reflect the biblical witness about christian mission as found in the new testament. For instance, it was silent about Jesus' love for the poor and his identification with the marginal and the oppressed. Furthermore, the Church-centered mission, espoused by western mission theorists, opened the door to fierce denominational competition and rivalry between western missions in seeking converts and planting churches. And this model also had no clear eschatological perspective. ${ }^{4}$

After Willingen (1952), the Church centered mission framework was no longer adequate for dealing with the problems facing churches engaged in mission. Those problems required a missio dei response, with a clearer understanding of the Trinitarian basis and nature of the Church's mission, and an openness and sensitivity to the eschatological character of the Kingdom, and the Church's subordinate relationship to it. ${ }^{5}$

In the third assembly of WCC in New Delhi (1961), the IMC was integrated to the WCC and became its commission on world mission and evangelism (CWME). This integration represented the beginning of the end of the Church-centered missionary view. The slogan of the first CWME consultation at Mexico city (1963) "six continent mission" represents a shift from the older church-centered mission framework to the emerging kingdom-oriented pattern. ${ }^{6}$

However, there is a danger in the acceptance of the new concept of mission as has occurred in some interpretations of the concept of Missio Dei. There has been a secular modification of the Missio Dei concept. ${ }^{7}$ Those who supported the wider understanding of the concept of Missio Dei tended to radicalize the view that the Missio Dei was larger than the mission of the Church, even to the point of suggesting that it excluded the Church's involvement. In this understanding, the Church has become unnecessary for the Missio $D e i{ }^{8}$ This excessive development of the meaning of Missio Dei contradicts with the intention of Karl Barth and Karl Hartenstein, who first used this term. By introducing the

\footnotetext{
${ }^{3}$ James A. Scherer, "Church, Kingdom, and Missio Dei: Lutheran and Orthodox Correctives to Recent Ecumenical Mission Theology", in The Good News of the Kingdom: Mission Theology for the Third Millennium, ed. Charles van Engen. (Maryknoll, NY: Orbis Books, 1993), 82.

${ }^{4}$ Scherer, "Church, Kingdom, and Missio Dei", 84.

${ }^{5}$ Ibid., 85 .

${ }^{6}$ Ibid., 83.

${ }^{7}$ Kwang Sun Kim, "Church, Missio Dei and the Kingdom of God".

${ }^{8}$ Bosch, Transforming Mission, 392.
} 
phrase, Hartenstein had hoped to protect mission against secularization and horizontalization, and to reserve it exclusively for God. ${ }^{9}$ This secular view of God's mission made the empirical church virtually dispensable as an agent of divine mission, and even a hindrance. $^{10}$

Therefore, according to Scherer, the main task of misssiology today is how to accomplish a successful transition from church-centered theology of mission to a kingdomoriented one without loss of missionary vision or betrayal of biblical content. ${ }^{11}$ Again Scherer says that abandoning the Church-centered framework in no way implies forsaking the Church's mission, but rather a revisioning of that mission from a fresh biblical, missiological, and above all, eschatological point of view. ${ }^{12}$

\section{Mission and the Kingdom of God}

The biblical idea of the Kingdom of God is deeply rooted in the Old Testament and is grounded in the confidence that there is one eternal, living God who has revealed himself to men and who has a purpose for the human race, that men will live together in peace, and God will judge between the nations, and also the evils of man's physical environment shall be no more. ${ }^{13}$

Jesus of Nazareth came with the announcement "repent, for the Kingdom of heaven is at hand." (Matt. 4:17). This theme of the coming of the Kingdom of God was the central in his mission. His teaching was designed to show men how they might enter the Kingdom of God (Matt. 5:20; 7:21). His mighty works were intended to prove that the Kingdom of God had come upon them (Matt. 12:28).

In western idiom, a kingdom is primarily a realm over which a king exercises his authority. The second meaning of a kingdom is the people belonging to a given realm. In the Old and New Testament, however, the meaning of kingdom primarily is the authority to rule, the sovereignty of the king. The word God's kingdom refers to his reign, his rule, his sovereignty. ${ }^{14}$

\footnotetext{
${ }^{9}$ Ibid.

${ }^{10}$ Scherer, "Church, Kingdom, and Missio Dei”, 86.

${ }^{11}$ Ibid., 82 .

12 Ibid., 85.

${ }^{13}$ George Eldon Ladd, "The Gospel of the Kingdom” in Perspectives on the World Christian Movement: A Study Guide, ed. Ralph Winter and Stephen Hawthorne (Pasadena, CA: William Carey Library, 1994), 64

${ }^{14}$ Ibid., 66.
} 
For Jesus, the Kingdom of God means abolishing the Kingdom of Satan. The authors of the New Testament understand that the only way the Kingdom of God will be brought about is by overthrowing the illegitimate kingdom now in place. This is the reason healing and exorcism played a central role in Jesus' ministry (Luke 11:20). This is what the Kingdom of God means. Whatever else the rule of God is about, it is about vanquishing the rule of Satan, and thus about setting people free from demons and from the ungodly infirmities they inflict on people. ${ }^{15}$

The New Testament proclaims that Jesus was victorious over the enemy in his ministry, death and resurrection, but Jesus and the New Testament authors see the ultimate realization of this kingdom victory in the future. The Kingdom has already come, but it has not yet been fully manifested in world history. In principle, Jesus won the war. Yet some battles must still be fought before the ultimate victory is fully manifested. ${ }^{16}$

Because of this, Jesus commissioned, equipped and empowered his disciples, and later the whole of the Church, to do the same. He set in motion the creation of a new humanity by giving us his power and authority to proclaim and demonstrate the Kingdom just the way he did. The Church is called to manifest the truth that God's kingdom has come and Satan's kingdom is defeated. Under the victorious authority of Christ, the Church is called to engage and overthrow evil powers just as Jesus has done. ${ }^{17}$

Ken Gnanakan asserts that the Church is the chosen vehicle of God's mission to the world. ${ }^{18}$ Jesus sent his disciples, and the Church to continue his mission to the end of this world. The Church is the witness to the Kingdom. Nevertheless, the Church should not be proud for the privilege and not to claim herself as the Kingdom. Arthur glasser says that the Church, in terms of local congregations and denominations, is not the Kingdom. This age is not for ecclesiastical self-deification but for the proclamation of the gospel of the Kingdom. And it is the age in which Christians should never cease to pray: "Thy Kingdom come!"19

The previous discussions suggest that the Church is the agent of god to proclaim that the Kingdom of God has come. The latter discussions talk about how to apply the

\footnotetext{
${ }^{15}$ Gregory A. Boyd, "God at War" in Perspectives on the World Christian Movement: A Study Guide, ed. Ralph Winter and Stephen Hawthorne (Pasadena, CA: William Carey Library, 1994), 82-83.

${ }^{16}$ Ibid., 84-85.

${ }^{17}$ Ibid., 85 .

${ }^{18}$ Ken Gnanakan, Kingdom Concerns: A Biblical Theology of Mission Today (Leicester: InterVarsity Press, 1993), 73.

${ }^{19}$ Arthur F. Glasser, et al. Announcing the Kingdom: The Story of God's Mission in the Bible. (Grand Rapids, MI: Baker Academic, 2003), 225.
} 
concept of Kingdom-centered mission in Indonesian context. But previously I want to describe the current situation of Indonesia in which Christianity presents.

\section{Christian Relationship with Other Religions in Indonesia}

Indonesia which has the motto "Bhinneka Tunggal Ika" (unity in diversity) is a multi religious-cultural society. The big world religions live and flourish among Indonesian people. Islam is Indonesia's main religion, with $88.22 \%$ of all Indonesians (177,528,772 people) declared as muslim according to the 2000 religious census, making Indonesia the most populous muslim-majority nation in the world. The remaining population is $8.92 \%$ Christians (of which roughly three quarters are Protestant, with the remainder mainly Catholic, and a substantial Charismatic minority), $1.81 \% \underline{\text { Hindus }}$ and $0.84 \%$ Buddhists, with small communities of Jews. ${ }^{20}$ Confucianism that came by Chinese people has some believers among Indonesian Chinese. Although muslims are the majority, Indonesia is not an Islamic state. The state is governed by the five principles (Pancasila) stated by the founding fathers which guarantee a freedom for every believers to perform their own religious life according what they believe.

Besides the world religions from outside, there are many local, tribal religions among Indonesian people, mostly categorized as animism. For example, in Java there are some local beliefs among Javanese. In Kalimantan there is Kaharingan, a belief that is professed by Dayak people. In north Sumatra there is Permalin that is professed by Batak people. ${ }^{21}$ Because of the policy of the government, Indonesians are required to declare themselves as the adherent of one of the five official religions (Islam, Protestant Christianity, Catholicism, Hinduism, and Buddhism). As a result, many Indonesians privately follow animist traditions or syncretism in spite of declaring themselves as adherents of the official religions. ${ }^{22}$

Christianity, even though a minority, is the most growing religion in Indonesia. The number of Christians has increased from 8.74 million in 1971 to 17.95 million in 2000, or 9.21 million during the period 1971-2000. The average growth rate of Christianity was $2.48 \%$ annually, meanwhile the growth rate of the Indonesian population as a whole was

\footnotetext{
${ }^{20}$ http://en.wikipedia.org/wiki/Indonesia\#Demographics; Suryadinata. Diakses 7 Pebruari 2010.

${ }^{21}$ Djohan Effendi, "Religious Plurality in Indonesia. Realism and its Problems," Gema Duta Wacana Theological Journal, no. 47(1994): 16.

${ }^{22} \mathrm{http}: / /$ en.wikipedia.org/wiki/Indonesia\#Demographics
} 
1.83\%. As a result, the percentage of Christians has also risen, from $7.39 \%$ in 1971 to $8.92 \%$ in $2000 .^{23}$

Another fact is that Christians are numerically a small minority of Indonesian people, but economically and socially rather privileged. Because of that, Abednego, an indonesian theologian, says Indonesian churches are easily tempted to show arrogant religious life: building luxurious church buildings, organizing mass evangelistic campaigns, etc. ${ }^{24}$

From the Dutch Colonial era, Christianity, both Protestantism and Catholicism, came to Indonesia with the more organized mission rather than other religions. ${ }^{25}$ The missionaries established many good schools, colleges, and hospitals; which now are the prominent public services, especially in urban areas.

Christian communities live mostly in urban area. According to 1971 census, among young people who live in urban areas sixteen percents are Christians. ${ }^{26}$ Regarding that fact, Hoekema argues that before 1971 the gospel has attracted especially young people. They might be impressed by the image of modernization, especially in education, which accompanies the Churches in many places. This is true especially for Javanese and for Chinese Indonesians who live in Java. ${ }^{27}$

The success of Christian mission in Indonesia has given rise to the awareness of the muslims. This awareness had some connection with the resurgence of Islam around the world. Muslims were alarmed by the growing of Christianity so that they attempted to prevent the conversion from Islam to Christianity. According to Hoekema, one of the background factors that restricted evangelization in Indonesia was the growing role, both internationally and nationally, of Islam. ${ }^{28}$

The economic power growth of the middle east nations, caused by oil wealth, played the significant role in empowering self identity of Islamic nations. The rich Islamic nations helped the weak Islamic nations to have confidence in resisting the influence of

\footnotetext{
${ }^{23}$ Leo Suryadinata et al., Indonesia's Population: Ethnicity and Religion in a Changing Political Landscap (Singapore: Institute of South East Asian Studies, 2003), 104.

${ }^{24}$ Benjamin Abednego, "Church Growth in East Java: The Call to be Servants of God", International Review of Mission, Vol. LXIII, no. 251, 1974, 354.

${ }^{25}$ Effendi, "Religious Plurality in Indonesia", 15.

${ }^{26}$ Calvin Jones, "Religion and Education in Indonesia," Indonesia, no. 22, 1976, 31-35.

${ }^{27}$ Alle G. Hoekema, "Recent Church Growth in Indonesia" in Exploring Church Growth, ed. Wilbert R. Shenk (Grand Rapids: Eerdmans, 1983), 32.

${ }^{28}$ Ibid, 33 .
} 
western culture including Christianity. The resurgence of Islamic world had impacts on inter-religious relationship, especially in Indonesia. ${ }^{29}$

The relationship between Christian mission and Islamic da'wah in Indonesia is characterized not only by competition but also by conflicts. Conflicts between the two communities that lead to civil wars causing thousands people killed has been happening in some areas such as Ambon, Tentena, Poso, and some other places.

Since 1997 Indonesia has been struggling to recover from the economic crisis. The crisis has changed the political situation from Suharto's totalitarian government to a more democratic government. The new governments have been attempting to rebuild a new order. But unfortunately those religious conflicts took place so that the focus to rebuild the country was distracted. The poor relationship of inter-religious communities, especially between Muslims and Christians, does not have any support to the establishment of the peaceful and prosperous country. Indonesian people long for such a life.

\section{Understanding Church's Mission in Indonesian Context}

How to understand church's mission regarding religious plurality in Indonesia? How should Indonesian churches do their mission without making worse the inter-religious relationship in Indonesia? How can the Churches take part in promoting peaceful life while promoting the gospel among Indonesian people? In this section these questions will be answered regarding the previous discussion above.

According to the previous discussion the purposes of mission are: (1) to proclaim the Kingdom of God that has come in the life and ministry of Jesus Christ; and (2) to invite people of every nations, cultures and religions to come and believe in Jesus Christ and to receive the salvation that graciously is given by god to everyone who believe in Jesus Christ.

In this understanding we always expect the conversion of as many as people who like to come and follow Jesus Christ and to join in his community. Conversion in this sense means repentance from their sin and believing in God and obeying his will revealed in the Bible.

However, it does not mean that Christians would show arrogant attitude to other religions because of having the absolute truth. The truth does not belong to Christians, but

\footnotetext{
${ }^{29}$ Frank L. Cooley, "Panggilan Kristen dalam Hubungan antar Umat Beragama" [The Christian Calling in Inter-religious Relationship] in Konteks Berteologi di Indonesia, ed. Eka Darmaputera, (Jakarta: BPK Gunung Mulia, 1991), 168.
} 
to God. Christians is not the owner of the truth but the witness to the Kingdom and the truth. Sidjabat, an Indonesian theologian, suggests, "instead of showing the superiority of Christianity over other religions, we should realize that the Christians are only witness for the decisive event in the life of Jesus."

It is true that God the Spirit works over the world, among all people of every nation and religion. There is possibility that God works in his way outside the Church. $\mathrm{He}$ can reveal himself directly to people even though they never heard the Gospel. It is the intention of God that many people come to the fullness of relationship with god through the faith in Jesus Christ.

Indonesian Christians live in one nation with those who still want to remain in their religion or who never heard the true information about the Christian faith. We need to respect their sincere heart to seek God and to live devoutly. We can consider them as Godfearers. As we continue to give witness to them, believing that God is working in them, we expect that one day they come to Jesus Christ. An aggressive evangelism is not recommended for Indonesian context because it will create resistance and inter-religious conflict.

Indonesian society is characterized by its religiosity, toleration and deliberation. Based on the trait of toleration, Indonesian religious groups do not make attacks and degrade the beliefs of other religious groups. On the basis of Indonesian way of life attacking other religious belief is forbidden in the interest of social order. ${ }^{31}$ Indonesian churches need to move forward wisely and prudently. Any form of evangelization need to be examined deliberately so that we do not use any method which is considered attacking other faiths.

Planting new churches has importance in Christian mission. The Church plays a significant role in nurturing and nourishing the faith of believers. The Church is the agent of God to proclaim his Kingdom in the community. If this is the case, planting new churches and inviting others to join in the Church still have great importance in mission. However, establishing a church is a means, not a goal. The main purpose is to proclaim the Kingdom of god.

\footnotetext{
${ }^{30}$ Walter Bonar Sidjabat, Religious Tolerance and the Christian Faith.A Study Concerning the Concept of Divine Omnipotence in the Indonesian Constitution in the Light of Islam and Christianity. (Jakarta: BPK Gunung Mulia, 1982), 173.

${ }^{31}$ Th. Sumartana, Mission at the Cross Roads.Indigeneous Churches, European Missionaries, Islamic Association and Socio-Religious Change in Java 1812-1936. (Jakarta: BPK Gunung Mulia, 1993), 332.
} 
Because of the main purpose of Church mission is the Kingdom of God, the ministry of the Church in society has a great importance. Kingdom of God transformed not only the individuals but also the society. The coming of the Kingdom means the changing of life's atmosphere toward justice, truth and peace. Therefore the Church needs to work to infect people with hope, love and responsibility for the world.

The Kingdom of God has come for Indonesian people too. Therefore Indonesian churches need to participate in promoting the justice, truth and peaceful life among Indonesian people. Church should help people to see the signs of the Kingdom. Indonesian churches needs to give more attention on this matter because church planting has been absorbing the most resources of the Church.

Considering this understanding of mission in Indonesian context, I want to suggest two strategic concepts of mission for Indonesian churches: wholistic concept of church growth and inter-religious dialogue.

\section{Wholistic Concept of Church Growth}

It must be acknowledged that the concept of church-centered mission still prevails among the Churchmen and mission practitioners in Indonesia. Considering that it is difficult to change instantly the mind of the mission practitioners from the Church-centered understanding of mission to Kingdom-centered understanding, we need to find a model that bridges the two understandings of mission. In order to answer this question, I would like to recommend a model of wholistic church growth as suggested by Orlando Costas. ${ }^{32}$ In my opinion this is one of the most suitable church growth models for Indonesian context.

Wholistic church growth is the process of integral and normal expansion that can and should be expected from the life and mission of the Church. The Church should experience growth in four directions: in the reproduction of its members (numerical growth), the development of its organic life (organic growth), the deepening of its understanding of the faith (conceptual growth), and the efficacy of its service in the world (diaconal growth). ${ }^{33}$

Firstly, one of the purposes of the Church is numerical growth that means reproduction of membership through the proclamation and living witness of the gospel and

\footnotetext{
${ }^{32}$ Orlando E. Costas, "A Wholistic Concept of Church Growth" in Exploring Church Growth, ed. Wilbert Shenk. (Grand Rapids: Eerdmans, 1983), 95-107.

${ }^{33}$ Ibid., $100 \& 102$.
} 
the incorporation of those who respond to the fellowship of a local congregation. Secondly, it must be balance with organic growth, internal development of the community of faith that covers the Church's form of government, financial structure, patterns of leadership, the type of activities in which it invests its time and resources, and its liturgical celebration. The quantity growth should be balance with quality growth.

Thirdly, conceptual growth which means the deepening understanding of the Scripture, the historical development of Christian doctrine and the world in which it lives and ministers, should have significance in Church's life. Fourthly, the inward growth must be balanced with the outward growth, the diaconal growth. Diaconal growth is the intensity of the Church's service in the world as a concrete demonstration of God's redemptive love. This dimension covers the Church's ministry in social environment; the contribution of the Church to the alleviation of human pain, for those in poverty and oppression.

\section{Inter-Religious Dialogue and Christian Witness}

Mukti Ali, an Indonesian Muslim leader and the former minister of religious affairs of Indonesian government, says:

We live today in a pluralistic world-pluralistic in cultural values, traditions, faiths and religions. Our problem is how in this pluralistic world we can live together not only in peace but also in trust and loyalty to each other...It is for this purpose that a dialogue among adherents of different religions must be conducted...In this pluralistic world of ours, dialogue is a conditio sine qua non. It is very urgent, and it will open new possibilities. ${ }^{34}$

Mukti Ali indicated the need for dialogue between religions in Indonesia. He raised this issue not only as a Muslim leader but also as a national leader. Indonesia is a pluralistic nation which needs the unity of all elements of the nation to seek peace and prosperity of the nation's life.

Inter religious dialogue is often identified with pluralism. It is true that for pluralists, inter religious dialogue is a primary avenue toward universal religious truth, the supreme truth that transcend various religious tradition. Meanwhile for the conservatives,

\footnotetext{
${ }^{34}$ H.A. Mukti Ali, "Religions, Nations and the Search for a World Community" in Christian-Muslim Dialogue, ed. S.J. Samartha. (Geneva: World Council of Churches, 1973), 19-20.
} 
dialogue is considered to involve compromise with anti Christian forces, so that is why many conservatives usually reject inter religious dialogue. ${ }^{35}$

I take the position claiming biblical truth that salvation is from Jesus Christ alone, through his death and resurrection. But it does not mean that inter religious dialogue should be rejected. The Uppsala statement says:

A Christian's dialogue with another implies neither a denial of the uniqueness of Christ, nor any loss of his own commitment to Christ, but rather that a genuinely Christian approach to others must be human, personal, relevant and humble. In dialogue we share our common humanity, its dignity and fallenness, and express our common concern for that humanity. ${ }^{36}$

Regarding the context of Indonesia, with its multi religious society, inter religious dialogue is an important matter. We can accept inter religious dialogue without surrendering biblical absolutes. There are some benefits of inter religious dialogue. Inter religious dialogue is a good way to reduce prejudice, tension and disharmony among religions. There were so many tensions and conflicts happened among Indonesian people because of religious difference. But starting in the late 1960s the Christian and other religious leaders held open and friendly dialogues in different levels. Even though there were so many hindrance for the success, those inter religious dialogues were successful in reducing tensions. ${ }^{37}$

The basis of inter religious dialogue, according to Lesslie Newbigin, is the faith in God's final revelation in Jesus Christ. ${ }^{38}$ John Stott says, "the basis of dialogue for Christians is founded in the bible itself. The living God of the biblical revelation himself enters into a dialogue with man. He not only speaks but listens. He asks questions and waits for the answers." 39

Jesus, when he was a boy, was found in the temple 'sitting among the teachers listening to them and asking them questions' (Luke 2:46). During his public ministry he entered into serious conversations with individuals like Nicodemus (John 3), a Samaritan woman (John 4), and a rich ruler (Luke 18:18-29).

\footnotetext{
${ }^{35}$ Steven J. Pierson, "Dialogue," in Evangelical Dictionary of World Mission, ed. A Scott Moreau. (Grand Rapids, MI: Baker, 2000), 274.

${ }^{36}$ World Council of Churches, 4 th, Uppsala,Report II. (Geneva, 1968), paragraph 6.

${ }^{37}$ T. K. John, "Inter Religious Dialogue" in A Dictionary of Asian Christianity, ed. Scott W Sunquist. (Grand Rapids MI: Eerdman, 2001), 388.

${ }^{38}$ Lesslie Newbigin, “The Basis, Purpose and Manner of Inter-Faith Dialogue," Inter-Religious Dialogue, ed. Richard W. Rousseau. (Ridge Row Press, 1981), 25.

${ }^{39}$ John R. W. Stott, Christian Mission in the Modern World. (Downers Grove: InterVarsity Press, 1975), 61.
} 
Paul in his missionary work used dialogue as an integral part of his method. Luke, the writer of acts, often uses the verb dialegomai that means 'to converse' or 'to discuss' to describe an aspect of Paul's evangelism. In the synagogue at Thessalonica for three weeks 'Paul argued with them from the scriptures' (acts 17:1-4). In Athens, he argued both in the synagogue with the jews and devout persons, and in the market place every day with those who chanced to be there (acts 17:16-34). In Corinth he argued in the synagogue every Sabbath and persuaded Jews and Greeks (18:4), while at Ephesus he spoke boldly, arguing and pleading about the Kingdom of God and then for two years he argued daily in the hall of Tyrannus (acts 19:8-10). ${ }^{40}$

Dialogue and witness are closely linked in the 'ecumenical affirmation.' though they can be distinguished, they are not mutually exclusive. Dialogue, being subsumed under the head of 'witnessing,' is an aspect of Christian witness. ${ }^{41}$ Kuk Il Han, professor of missiology at Presbyterian college and theological seminary, says that dialogue is not designed for us to give up proclaiming the Gospel. It is aimed to be an instrument of mission. Dialogue is an opportunity to confess and share Jesus Christ with non-believers. ${ }^{42}$

For evangelicals, inter religious dialogue is not altogether rejected. The Lausanne covenant says, "our Christian presence in the world is indispensable to evangelism, so is that kind of dialogue whose purpose is to listen sensitively in order to understand." But the document also says that evangelism is proclamation of the historical, biblical Christ as Savior and Lord. ${ }^{43}$ It means that for evangelicals dialogue is a method of mission. According to Arthur Glasser, the dialogic method is necessary if those who witness to Christ are to engage the minds of their listeners - they must listen and learn as well as speak and instruct. ${ }^{44}$

\section{Conclusion}

The world history, with Christian missionary movement in it, has caused the change of the concept of mission. The concept of church-centered mission is now being understood not only historically improper but also unsatisfying biblically. The Kingdom-

\footnotetext{
${ }^{40}$ Ibid., 62.

${ }^{41}$ Eeuwout Klootwijk, Commitment and Openness: The Interreligious Dialogue and Theology of Religions in the Work of Stanley J. Samartha. (Uitgeverij Boekencentrum B U: Zocktermeer, 1992), 295.

${ }^{42}$ Kuk Il Han, "Witness and Dialogue: The Study of the Dialogue Between Christianity and Other Religions," Mission and Theology, Vol. 7, Spring 2001, 289.

${ }^{43}$ The Lausanne Covenant, "Let the Earth Hear His Voice,". (Minneapolis: World Wide Publications, 1975), point 4.

${ }^{44}$ Arthur Glasser, "A Paradigm Shift? Evangelicals and Interreligious Dialogue," in Contemporary Theologies of Mission, ed. Glasser and McGavran. (Grand Rapids: Baker, 1983), 209.
} 
centered concept is an alternative one for mission if this age. But the problem is, as James Scherer points out, how to accomplish a successful transition from an earlier churchcentered theology of mission to a Kingdom-centered one without loss of missionary vision or betrayal of biblical content. In terms of the context of mission in Indonesia, the Kingdom-centered theology of mission can be applied at least in two concepts of mission: wholistic church growth and inter-religious dialogue in the balance with Christian witness.

\section{Bibliography}

Abednego, Benjamin. "Church Growth in East Java: The Call to be Servants of God". International Review of Mission LXIII, no. 251 (1974): 354.

Ali, H. A. Mukti. "Religions, Nations and the Search for a World Community" in Christian-Muslim Dialogue, edited by S.J. Samartha. Geneva: World Council of Churches, 1973.

Bosch, David J. Transforming Mission. Paradigm Shifts in Theology of Mission. Maryknoll NY: Orbis Books, 1991.

Boyd, Gregory A. "God at War" in Perspectives on the World Christian Movement: A Study Guide, ed. Ralph Winter and Stephen Hawthorne. Pasadena CA: William Carey Library, 1994.

Cooley, Frank L. "Panggilan Kristen dalam Hubungan antar Umat Beragama" [The Christian Calling in Inter-religious Relationship] in Konteks Berteologi di Indonesia, edited by Eka Darmaputera. Jakarta: BPK Gunung Mulia, 1991.

Costas, Orlando E. "A Wholistic Concept of Church Growth" in Exploring Church Growth, edited by Wilbert Shenk. Grand Rapids: Eerdmans, 1983.

Effendi, Djohan. "Religious Plurality in Indonesia: Realism and its Problems." Gema Duta Wacana Theological Journal, no. 47 (1994): 16.

Glasser, Arthur. "A Paradigm Shift? Evangelicals and Interreligious Dialogue," in Contemporary Theologies of Mission, edited by Glasser and McGavran. Grand Rapids: Baker, 1983.

Glasser, Arthur F, et al. Announcing the Kingdom: The Story of God's Mission in the Bible. Grand Rapids MI: Baker Academic, 2003.

Gnanakan, Ken. Kingdom Concerns: A Biblical Theology of Mission Today. Leicester: Inter-Varsity Press, 1993.

Han, Kuk Il. "Witness and Dialogue: The Study of the Dialogue Between Christianity and Other Religions," Mission and Theology 7, Spring (2001): 289.

The Lausanne Covenant, "Let the Earth Hear His Voice,". Minneapolis: World Wide Publications, 1975.

Hoekema, Alle G. "Recent Church Growth in Indonesia" in Exploring Church Growth, edited by Wilbert R. Shenk. Grand Rapids: Eerdmans, 1983.

John, T. K. "Inter Religious Dialogue" in A Dictionary of Asian Christianity, edited by Scott W Sunquist. Grand Rapids MI: Eerdman, 2001. 
Jones, Calvin. "Religion and Education in Indonesia." Indonesia, no. 22 (1976): 31-35.

Klootwijk, Eeuwout. Commitment and Openness: The Interreligious Dialogue and Theology of Religions in the Work of Stanley J. Samartha. Uitgeverij Boekencentrum B U: Zocktermeer, 1992.

Ladd, George Eldon. "The Gospel of the Kingdom" in Perspectives on the World Christian Movement: A Study Guide, edited by Ralph Winter and Stephen Hawthorne. Pasadena CA: William Carey Library, 1994.

Neill, Stephen. A History of Christian Missions. Harmondsworth: Penguin, 1966.

Newbigin, Lesslie. "The Basis, Purpose and Manner of Inter-Faith Dialogue," InterReligious Dialogue, edited by Richard W. Rousseau. Ridge Row Press, 1981.

Pierson, Steven J. "Dialogue," in Evangelical Dictionary of World Mission, edited by A Scott Moreau. Grand Rapids MI: Baker, 2000.

Scherer, James A. "Church, Kingdom, and Missio Dei: Lutheran and Orthodox Correctives to Recent Ecumenical Mission Theology", in The Good News of the Kingdom: Mission Theology for the Third Millennium, edited by Charles van Engen. Maryknoll NY: Orbis Books, 1993.

Sidjabat, Walter Bonar. Religious Tolerance and the Christian Faith: A Study Concerning the Concept of Divine Omnipotence in the Indonesian Constitution in the Light of Islam and Christianity. Jakarta: BPK Gunung Mulia, 1982.

Stott, John R. W. Christian Mission in the Modern World. Downers Grove: Inter Varsity Press, 1975.

Sumartana, Th. Mission at the Cross Roads: Indigeneous Churches, European Missionaries, Islamic Association and Socio-Religious Change in Java 1812-1936. Jakarta: BPK Gunung Mulia, 1993.

Suryadinata, Leo, et al. Indonesia's Population: Ethnicity and Religion in a Changing Political Landscap. Singapore: Institute of South East Asian Studies, 2003. 